УДК 699.8;693.6

О.О. Попов 1 * к.т.н., доцент

I. М. Бабій $2^{*}$ к.т.н., доцент

Є. Ю. Кальченя $3^{*}$ аспірант

А. М. Гострик $4^{*}$ аспірант

1* Кафедра технології будівельного виробництва, Одеська державна академія будівництва та архітектури, вул. Дідріхсона, 65029, Одеса, Україна, тел. +38(048) 7236151, e-mail: oleg.a.popov@gmail.com, ORCID: 0000-00034021-5199

$2 *$ Кафедра технології будівельного виробництва, Одеська державна академія будівництва та архітектури, вул. Дідріхсона, 65029, Одеса, Україна, тел. +38(048)7716969,

e-mail: igor7617@gmail.com, ORCID ID: 0000-0001-8650-1751

3*Кафедра технології будівельного виробництва, Одеська державна академія будівництва та архітектури, вул. Дідріхсона, 65029, Одеса, Україна, тел. +38 (048) 7236151, e-mail: yevhenii.kalchenya@gmail.com

4 ККафедра технології будівельного виробництва, Одеська державна академія будівництва та архітектури, вул. Дідріхсона, 65029, Одеса, Україна, тел. +38 (048) 7236151, e-mail: anna.gostryk16@gmail.com, ORCID: 00000002-1638-0912

\title{
ВИБІР РАЦІОНАЛЬНОГО КОНСТРУКТИВНО-ТЕХНОЛОГІЧНОГО РІШЕННЯ УЛАШТУВАННЯ ТЕПЛО- ТА ЗВУКОІЗОЛЯЦІї ПІДЛОГИ
}

\begin{abstract}
Анотація. В статті розглянуто вирішення важливої проблеми вибору раціональних технологічних рішень улаштування тепло-, та звукоізолящії підлог у житловому будівництві шляхом проведення порівняльного аналізу. Для цього використовувалися результати порівняльного аналізу організаційно-технологічних показників при влаштуванні звукоізолящї підлоги з використанням різних матеріалів і їх конструктивних особливостей. Порівняльний аналіз технологій улаштування звукоізоляції підлоги дозволив визначити раціональний варіант, згідно єдиної бальної шкали, яким є конструктивно-технологічне рішення багатошарової системи звукоізоляиї підлоги на основі матеріалу Isolon 500 - Tun 1.

Ключові слова: звукоізоляція підлоги, повітряний шум, ударний шум, порівняльний аналіз, багатошарова система.
\end{abstract}

Постановка проблеми. Робота присвячена вирішенню важливої проблеми вибору раціональних технологічних рішень улаштування тепло-, та звукоізоляції підлог у житловому будівництві шляхом проведення порівняльного аналізу. Для цього використовувались результати порівняльного аналізу організаційно-технологічних показників при влаштуванні звукоізоляції підлоги з використанням різних матеріалів та їх конструктивних особливостей.

Аналіз публікацій. Однією з важливих технологічних задач сьогодення в будівництві є захист від різноманіття шумів. Тому одним з важливих будівельних процесів є улаштування звукоізоляції стін, перегородок, перекриттів і покриттів для створення комфортних умов перебування людини в приміщеннях різного призначення. Вібрація, викликана надмірним шумом, поширюється по всіх взаємозалежних між собою несучих та огороджувальних конструкцій і проникає в усі приміщення будинку.

У свою чергу при будівництві чи опорядженні житлових будинків особливу увагу необхідно приділити звукоізоляції внутрішніх стін і перекриттів. Їх часто влаштовують з традиційних матеріалів не достатньої товщини, що не є суттєвою перешкодою для повітряних шумів. Слід відзначити, що для вирішення питань звукоізоляції необхідно перш за все чітко уявляти з якими видами шумів необхідно боротися, та по-друге - для яких конструкцій будинків чи споруд використати ту чи іншу систему звукоізоляції.

В будинках, що будуються, так і в раніше збудо-

ваних будівлях, все більше місце займає проблема міжповерхової ізоляції перекриття. В значній мірі це відноситься до нових житлових будинків з вільним плануванням [1]. На етапі будівництва небезпека влаштування неправильної ізоляції ударного шуму набагато менша. Тому комплексне рішення питання влаштування звукоізоляційної стяжки по всіх площах будівлі в цілому, значно спрощує створення комфорту в житлових та офісних приміщеннях, що в немалому ступені може призводити до збільшення конкурентоспроможності приміщень житлового та ділового призначення $[2,3]$. Але, не завжди ці проекти ефективні, тому що не до кінця дослідженні всі можливості по оптимізації як в організації проектів, так і при виборі технологічних рішень [4].

Шум, проникаючий із сусідніх по вертикалі приміщень, буває повітряним, ударним та структурним [5]. Конструкція підлоги, розміщеного над перекриттям, мало впливає на загальну величину звукоізоляції. Тут, перш за все, важлива величина загальної масивності $1 \mathrm{~m}^{2}$ перекриття 3 підлогою, i якщо вона більша $350 \kappa г / \mathrm{m}^{2}$, то потрібна звукоізоляція повітряного шуму в цілому забезпечується. Для ізоляції ударного шуму також важлива масивність перекриття, але для забезпечення нормативів вона повинна бути в декілька разів більше, ніж для нормативів по повітряному шуму, що ні технічно, ні економічно край не раціонально. Для ізоляції ударного шуму більш ефективне використання спеціальних конструкцій підлог $[5,6]$. 
Ціль роботи. Ціллю даної роботи являється вибір і обгрунтування конструктивно-технологічних рішень тепло-, та звукоізоляції підлог у житловому будівництві на основі порівняльного аналізу.

Виклад матеріалу. Відомо [7, 8], що в перекритті, ефективність захисту від повітряного шуму в більшості залежить від маси матеріалу конструкції на одиницю її площі. Тобто необхідний рівень ізоляції від повітряних шумів досягається конструкцією самого монолітного залізобетонного перекриття. Навпаки, вирішити проблему ізоляції від ударних і структурних шумів самим лише монолітним перекриттям чи способом потовщення його не являється можливим. Це конструктивно-технологічне рішення може спровокувати значну матеріалоємність та матеріальні витрати, а також привести до значного навантаження на фундаменти та основу. Тому для ізоляції від ударного і структурного шуму необхідний пошук більш ефективних конструктивно-технологічних рішень підлог.

Порівняльні дослідження на основі багатокритеріального аналізу проводились 3 використанням конструктивно-технологічних рішень підлог на основі різних інноваційних матеріалів для тепло-, та звукоізоляції. в натурних умовах в приміщеннях збудованої будівлі між другим та третім поверхом, в яких підлога влаштована без фінішного оздоблення з декількома різними конструктивно-технологічними рішеннями на основі наступних матеріалів, рис.1:

- рулонний матеріал "Акуфлекс", основу якого складають спеціально оброблені поліефірні волокна, розроблені у відповідності актуальним вимогам по акустиці приміщень і служать для поглинання ударного шуму. Матеріал використовується в якості звукоізоляційної підкладки в конструкціях плаваючих підлог, яка являється шаром між стяжкою та фінішним покриттям підлоги (лінолеум, ламінат, паркет). Окрім цього, "Акуфлекс" може служити пружним шаром під вирівнюючою стяжкою для додаткової ізоляції від ударного шуму;

- еластичний закритопористий пінополіетилен із зшитою молекулярною структурою Isolon 500, представлений в широкому діапазоні товщин (0,8-50 мм)

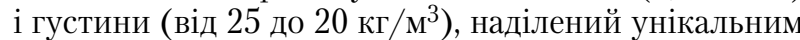
поєднанням фізичних та хімічних властивостей. Переваги Isolon 500 над мінераловатними плитами, які традиційно застосовуються, пінополістиролом, екструдованим полістиролом, пінополіуретаном, м'якими дерево-волокнистими плитами та іншими, полягає, насамперед, в необхідній меншій товщині матеріалу, в екологічній чистоті і збереженні стабільності всіх основних експлуатаційних властивостей (теплоізоляційних і акустичних показників, вологостійкості і гідрофобності, пружності та еластичності) на довготривалий період часу при різних умовах експлуатаціі;

- шумоізоляційний шар на основі матеріалу Gum Gum Spray. Використовують для звукоізоляції від ударних шумів.

Для визначення показників, а саме індексу приведеного ударного шуму, дБ, та індексу ізоляції повітряного шуму, дБ, що застосовуються в багатокритеріального аналізу проводилися, як зазначалося раніше, натурні дослідження.

Таким чином, були влаштовані наступні конструктивно-технологічні схеми підлог, а саме: Тип 1 (76 мм - ц/п стяжка М 150, плівка РЕ, 8 мм - підкладка Isolon 500 (1 шар - 4 мм),180 мм - з/б плита); Тип 2 (75 мм - ц/п стяжка М 150, плівка PE, 6-8 мм - Gum-Gum Spray, 180 мм - 3/б плита; Тип 3(70 мм - ц/п стяжка М 150, 10 мм - підкладка Акуфлекс, 180 мм - з/б плита).

Згідно ДБН В.1.1-31:2013 "Захист територій, будинків і споруд від шуму" міжповерхове перекриття повинно мати індекс ізоляції повітряного шуму Rw ? 52 дБ, а індекс приведеного рівня ударного шуму під перекриттям Lnw - 55 дБ.

Вимірювання звукоізоляції приведеного ударного шуму складаються 3 наступних етапів: підготовка до дослідів приміщень; вимірювання рівнів ударного и повітряного шуму під перекриттям при проведенні над ним ударних дій; обробка результатів вимірювань.

Створення повітряного шуму в приміщеннях 3 влаштованими конструкціями підлоги проводилось 3 допомогою багатоспрямованого джерела звуку OEDSP360 зі штативом TRP005R. B свою чергу імітація ударного шуму проводилась 3 допомогою ударної машини УМ-10. Вимірювання шумів проходило 3 допомогою шумоміра "Экофизика-110A".

Досліди проводились за декілька етапів. На першому етапі були визначені показники індексу приведеного ударного і повітряного шумів. Було встановлено, що конструктивно-технологічні рішення підлог перекриття на основі досліджуваних матеріалів мають, практично, однакові показники. При цьому необхідно відзначити, найменшим індексом звукоізоляції від ударних шумів характеризується система підлоги на основі матеріалу Isolon 500 i дорівнює 46 дБ. Отримавши дані показники, представляло інтерес обрати раціональну схему влашту-

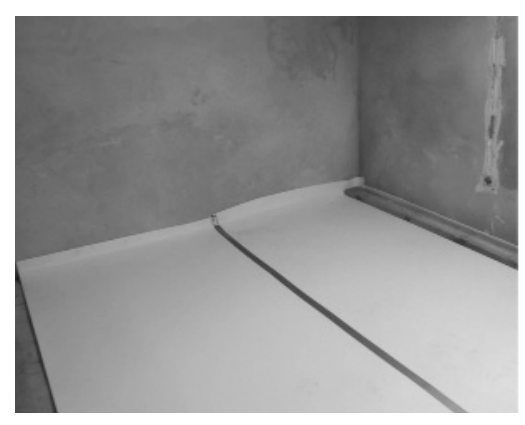

a)

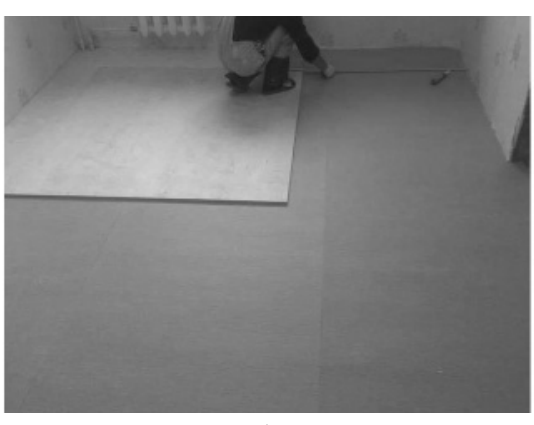

б)

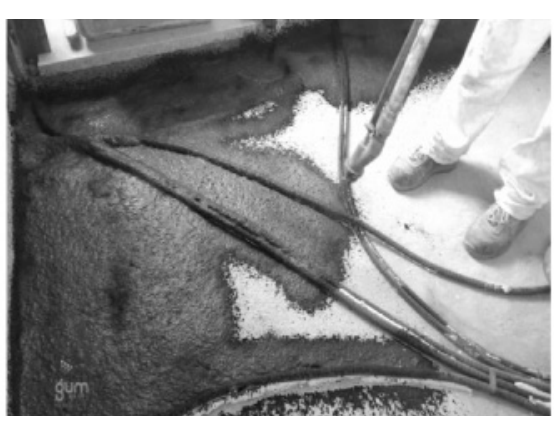

в)

Рис. 1. Влаштування систем тепло-, та звукоізоляції на основі наступних матеріалів: а) підкладка Isolon 500;

б) підкладка Акуфлекс; в) Gum-Gum Spray 


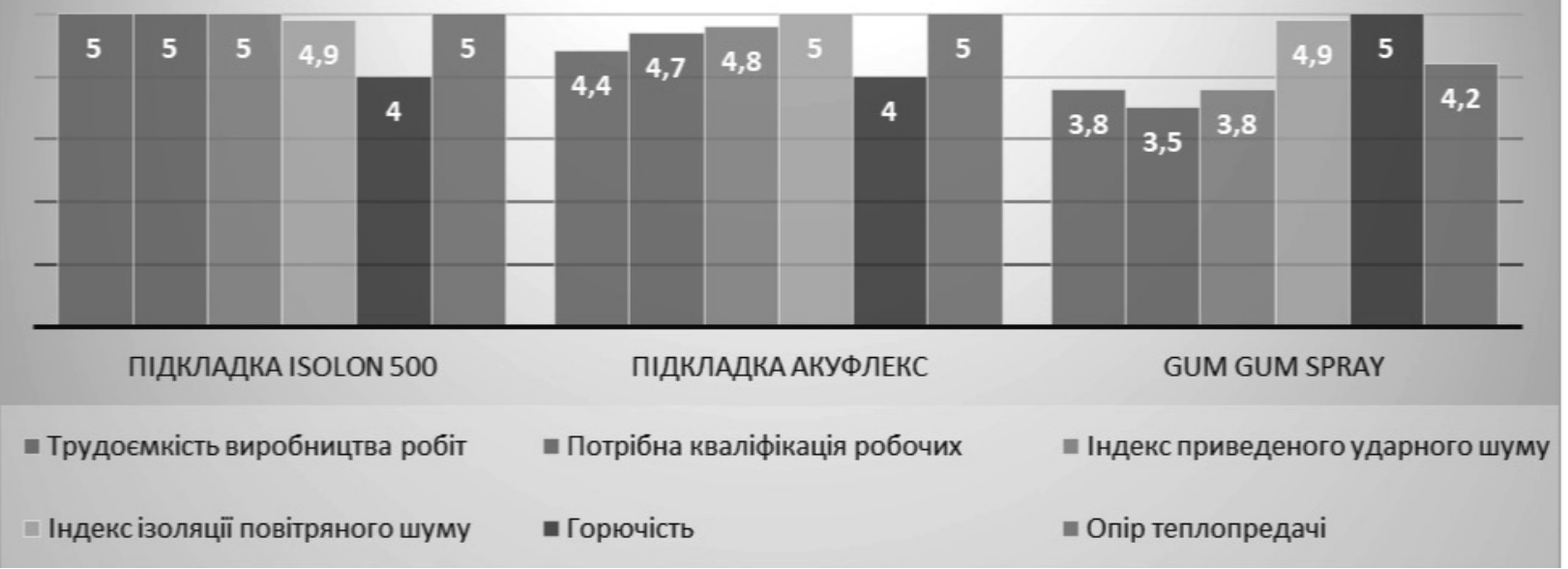

Рис.2. Діаграма порівняння за балами

вання підлог на основі багатокритеріального аналізу.

На наступному етапі обрані критерії порівняння обраних інновацій методів звукоізоляції підлог. Проведена якісна і кількісна оцінка технологічних альтернатив, за які прийнято наступні: трудоємність виробництва робіт, люд-зм.; необхідна кваліфікація робочих, середній розряд; індекс приведеного ударного шуму, дБ; індекс ізоляції повітряного шуму, дБ;

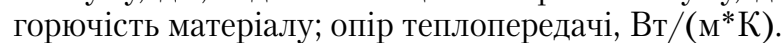

Критерії вибору мають багаторівневий підхід, який передбачає рішення багатьох задач: технічних, технологічних, експлуатаційних, економічних і екологічних.

Наступним етапом порівняльного аналізу являється отримання аналітичної залежності, яка відображує ступінь впливу вагомості критеріїв на раціональний вибір технологічного рішення [3].

Порівняння обраних технологій влаштування тепло-, та звукоізоляції підлог за приведеними критеріями здійснюється за допомогою діаграм, рис.2. Натуральні значення критеріїв переводяться в бали від 1 до 5, де найгіршим та найкращим значенням присвоєні бали 1 і 5 відповідно. Інші бали пораховані з допомогою інтерполяції. Технології, критерії і при- своєні їм бали представлені на діаграмі, що зображена на рисунку 2.

Аналіз даних діаграми дозволив встановити, що влаштування тепло-, та звукоізоляції із застосуванням Gum Gum Spray по обраних критеріях якості має показники, що значно поступаються показникам інших матеріалів для вирішення певних задач. При цьому потрібно вказати на його значну вартість у порівнянні з іншими розглянутими матеріалами. В свою чергу слід відзначити, що за обраними критеріями як кількісних, так і якісних показників найкращим рішенням буде влаштування підлог 3 використанням матеріалу Isolon 500 ? Тип 1.

Висновки і перспективи подалыших дослідів.

1. Порівняльний аналіз технологій влаштування звукоізоляції підлоги дозволив визначити найбільш раціональний варіант, згідно єдиної бальної шкали.

2. Результати дослідів на основі порівняльного аналізу дозволило визначити конструктивно-технологічне рішення багатошарової системи підлоги на основі матеріалу Isolon 500 - Тип 1.

3. В подальшому передбачається дослідження технологічних систем підлоги на основі інших матеріалів, наприклад, гумової крихти.

\section{Jimepamypa}

1. Дідковський В.С. Оцінка ізолящії повітряного шуму огороджувальних конструкцій в розширеному діапазоні частот/ В.С. Дідковський, В.П. Заєщь, Н.О. Самойленко// Электроника и связь. - 2011. - №1(60). - С. 164-168.

2. Бабий И.Н. Использование новых энергосберегающих технологий в проектируемой бизнес-гостинице "Аэропорт" / И.Н. Бабий, О.Ю. Багмет, Р.А. Яковенко //Міжвідомчий науково-технічний збірник (технічні науки) "Будівельне виробнищтво" НДІБВ, Київ, 2017. - Вип. №62/1 - С.64-70.

3. Менейлюк А.И. Выбор эффективных организачионно-технологчческих решений возведения жильх зданий / А.И. Менейлюк, И.С. Чернов // міжвідомчий наук.-техн. зб. "Будівельне виробництво". - Вип. 53. - Київ: НДІБВ, 2012. - C. 93-97.

4. Сенан А.М. К оценке звукоизоляции междуэтажных перекрытий / А.М. Сенан // Экологический вестник научных центров Черноморского экономического сотрудничества. Спецвыпуск. 2006. - С. 151-153.

5. Звукоизоляция и звукопоглощение. / Л.Г. Осипов, В.Н. Бобылев, Л.А. Борисов и др.; Под ред. Г.Л. Осипова, В.Н. Бобылева. М.: Изд-во Астрель, 2004.- 450 с.

6. Иванова Н.В. Социальная эффективность акустической комфортности жилья // "Вісник ХХПI". - Вип.1. - 3с. -Харків: МОУ, ХХПІ. -1999. - С.324-326. 


\title{
References
}

1. Didkovs?kyy V.S. Otsinka izolyatsiyi povitryanoho shumu ohorodzhuvalnykh konstruktsiy v rozshyrenomu diapazoni chastot/ V.S. Didkovskyy, V.P. Zayets, N.O. Samoylenko// ?lektronyka y soyaz?. - 2011. - №1(60). - S. $164-168$.

2. Babyy Y.N. Yspol?zovanye novykh nerhosberehayushchykh tekhnolohyy v proektyruemoy byznes-hostynytse "Aeroport" / Y.N. Babyy, O.YU. Bahmet, R.A. Yakovenko //Mizhvidomchyy naukovo-tekhnichnyy zbirnyk (tekhnichni nauky) "Budivel?ne vyrobnytstoo" NDIBV, Kyyiv, 2017.- Vyp. №62/1- S.64-70.

3. Meneylyuk A.Y. Vybor effektyvnykh orhanyzatsyonno-tekhnolohycheskykh reshenyy vozvedenyya zhylykh zdanyy / A.Y. Meneylyuk, Y.S. Chernov // mizhoidomchyy nauk.-tekhn. zb. "Budivel?ne vyrobnytstvo". - Vyp. 53. - Kyyiv: NDIBV, 2012. - S. 93-97.

4. Senan A.M. K otsenke zoukoyzolyatsyy mezhduetazhnykh perekrytyy / A.M. Senan // ekolohycheskyy vestnyk nauchnykh tsentrov Chernomorskoho ekonomycheskoho sotrudnychestva. Spetsvypusk. 2006.-S. 151-153.

5. Zvukoyzolyatsyya y zoukopohloshchenye. / L.H. Osypov, V.N. Bobylev, L.A. Borysov y dr.; Pod red. H.L. Osypova, V.N. Bobyleva. M.: Yzd-vo Astrel, 2004.-450 s.

6. Yvanova N.V. Sotsyal?naya effektyvnoste akustycheskoy komfortnosty zhyleya // "Visnyk KHKHPI". -Vyp.1. -3s. Kharkiv: MOU, KHKHPI. -1999. -S.324-326.

О. А. ПОПОВ $1^{*}$, к.т.н., доцент, ORCID: 0000-0003-4021-5199

И. Н.БАБИЙ 2* к.т.н., доцент, ORCID ID: 0000-0001-8650-1751

Е. Ю.КАЛЬЧЕНЯ $3 *$ аспирант

А. Н. ГОСТРИК $4 *$ аспирант

\section{ВЫБОР РАЦИОНАЛЬНОГО КОНСТРУКТИВНО-ТЕХНОЛОГИЧЕСКОГО РЕШЕНИЯ ПРИ УСТРОЙСТВЕ ТЕПЛО- И ЗВУКОИЗОЛЯЦИИ ПОЛА}

\begin{abstract}
Аннотация. В статье рассмотрено решение важной проблемы выбора ращиональных технологических решений устройства тепло- и звукоизолящии полов в жилищном строительстве путем проведения сравнительного анализа. Для этого использовались результаты сравнительного анализа организащионно-технологических показателей при устройстве звукоизолящии пола с использованием различных материалов и их конструктивных особенностей. Сравнительный анализ технологий устройства звукоизоляции пола позволил определить рациональный вариант, согласно единой баллвной шкаль, которым является конструктивно-технологическое решение многослойной системы звукоизоляци пола на основе материала Isolon 500 - Tun 1.
\end{abstract}

Ключевые слова: звукоизолячия пола, воздушный шум, ударный шум, сравнительный анализ, многослойная система.

O.O. POPOV $1 *$ Cand. Sc. (Tech.), Associate Professor ORCID: 0000-0003-4021-5199

I. N. BABIJ 2*, Cand. Sc. (Tech.), Associate Professor ORCID ID: 0000-0001-8650-1751

E. Yu. KALCHENYA 3*, Graduate student

A. N. HOSTRYK $4 *$, Graduate student

\section{CHOICE OF THE RATIONAL CONSTRUCTION AND TECHNOLOGICAL SOLUTION OF THE SUBMISSION OF HEAT AND SOUND INSULATION OF THE FLOOR}

\begin{abstract}
The article deals with the solution of an important problem of choosing rational technological solutions for the arrangement of heat and sound insulation of floors in residential construction through comparative analysis. For this purpose, the results of the comparative analysis of organizational and technological indicators for the installation of sound insulation of the floor using different materials and their design features were used. The comparative analysis of the technologies of the sound insulation of the floor flooring allowed to determine the rational variant according to the single point scale, which is the constructive and technological solution of the multilayer sound insulation system of the floor based on the material Isolon 500 - Type 1. Key words: floor sound insulation, air noise, shock noise, comparative analysis, multilayer system.
\end{abstract}

